\title{
Pricing and price competition in consumer markets
}

\author{
Ante Farm ${ }^{1}$
}

Received: 21 January 2016 / Accepted: 9 July 2016 / Published online: 26 July 2016 (C) The Author(s) 2016. This article is published with open access at Springerlink.com

\begin{abstract}
This paper offers a simple model of the price mechanism in markets where buyers take prices as given and prices are set by sellers, as in most consumer markets. It explains price competition by arguing that a market price goes down if-and only if - a price cut appears profitable to a firm even if its competitors follow suit. It also explains why markets do not always clear, that is, why production can be restricted by sales and not capacity at prices set by firms.
\end{abstract}

Keywords Oligopoly · Pricing · Price competition · Price leadership

JEL Classification D43 $\cdot$ L13

\section{Introduction}

Perfect competition is still the baseline model in introductory textbooks in economics. But not all firms can take the market price as given in a market where prices are set by firms. This paper argues, however, that there is a simple modification of the

\footnotetext{
Discussions with Jörgen Weibull and Henrik Horn during the first phase of the research reported here were very valuable. I would also like to thank Mats Bergman and participants of seminars at Stockholm University and Åbo Akademi University, and in particular Jim Albrecht, Mahmood Arai, Torsten Persson, Rune Stenbacka, Lars E.O. Svensson, Susan Vroman, Eskil Wadensjö and Johan Willner, for useful comments on earlier versions. Discussions with Nils Lindman, Lars-Erik Lögdberg and Stefan Norrman on pricing in practice have been very encouraging. I am also very grateful for constructive comments from two anonymous referees.
}

$凶$ Ante Farm

ante.farm@sofi.su.se

http://www.sofi.su.se

1 Swedish Institute for Social Research (SOFI), Stockholm University, 10691 Stockholm, Sweden 
traditional model which makes sense in markets where buyers take prices as given and prices are set by sellers, as in most consumer markets. For, even if not all firms can be price takers, all firms but one can take the price as given. And by replacing an imaginary auctioneer with a real price leader maximizing its individual profits, we obtain a consistent and tractable model with plausible assumptions and realistic predictions, including markets which do not always clear.

In this model the market price goes down if — and only if - a price cut appears profitable to a firm even if its competitors follow suit. Thus, the market price is determined by the lowest market price preferred by a firm, an idea which goes back at least to Boulding (1941, pp. 607-613). The basic idea is that if firms prefer the same market price, then the choice of price leader is immaterial, while if firms prefer different market prices - due to differences in costs or capacities or market shares - then a firm preferring the lowest market price will determine the market price simply by announcing it, while firms preferring a higher market price are forced to follow suit, at least if the price leader has excess capacity. And a firm preferring the lowest market price may be called a competitive price leader, to use the term introduced by Lanzillotti (1957).

To my knowledge, competitive price leadership has not been further developed or discussed in modern literature on pricing. Price leadership is not even mentioned in recent monographs or handbooks with only a few exceptions, including Scherer (1980). And most recent articles on price leadership, including Rotemberg and Saloner (1990), Hviid (1990), Deneckere and Kovenock (1992), Pastine and Pastine (2004) and Ishibashi (2008), only deal with collusive price leadership or Stackelberg price leadership. The paper by Seaton and Waterson (2013), however, is an empirical study of price leadership in the classical sense, based on price data from two leading British supermarket chains. They conclude that, even with a narrow definition, price leadership appears to be a very common phenomenon.

In classical writings a price leader is often a dominant firm. Markham (1951, pp. 895-896) notes that "nearly every major industry in the American economy has, in its initial stages of development, been dominated by a single firm", and that "the monopoly power of the initial dominant firm in most industries [...] was gradually reduced by industrial growth and the entrance of new firms". Hence it is easy to understand why 'dominant firm' price leadership dominates the classical literature and why it often is called 'partial monopoly'.

Price leadership has often been divided into three categories, namely dominant firm, collusive and barometric (Scherer 1980 p. 176), but without precise definitions. I find it clarifying, to begin with, to distinguish between collusive price leadership, where the price leader is assumed to maximize its industry's profits, and competitive price leadership, where the price leader is assumed to maximize its individual profits. And this paper only deals with competitive price leadership.

If there are many firms preferring the lowest market price, the choice of price leader among these is immaterial and may be expected to vary randomly or depend on which firm is assumed to have the best information on market conditions. A competitive price leader may in this case also be called a barometric price leader, following (Stigler 1947). And if there is only one firm preferring the lowest market price, it may be called a dominant price leader. 
The paper is organized as follows. Section 2 argues that while Cournot models and Bertrand models are applicable to commodity markets and markets with sealed bidding, respectively, Bolding models are applicable to consumer markets. In Sect. 3 we shall see how the outcome of competitive price leadership crucially depends on the way the market is shared between firms at different market prices. And the distribution of sales between firms depends in general not only on firms' capacities, as it does at market clearing, but also on consumers' preferences. The effects of capacities and preferences on pricing are analysed more in detail in Sect. 4, which also is a reappraisal of the classical model of price leadership by a dominant firm. And Sect. 5 concludes.

\section{Assumptions}

A fundamental assumption in this paper is that rational agents avoid dilemmas like the prisoner's dilemma if they can. In the well-known prisoner's dilemma two agents without ability to communicate have to choose between "cooperation" and "defection" and the dilemma is that both agents will be tempted to defect if they are rational even if cooperation would be better for both of them. Of course, game theory also tells us that repeated interaction will foster cooperation. But the basic source of the dilemma is the assumption that agents cannot communicate.

Now, when prices can be observed and revised at any time, as in consumer markets, firms are not forced into a dilemma which necessitates prediction of competitors' prices. In this paper price leadership is consequently developed within the framework of "no side payments and partial preplay communication", which Luce and Raiffa (1957, p. 169) once characterized as the most surprising omission in the literature on games. More precisely, I exclude all binding agreements and I also exclude all communication apart from observation of prices. In fact the model in this paper differs from most contemporary pricing literature by not using game theory at all. And this is because game theory is not needed to explain pricing and price competition in markets where buyers take prices as given and prices are set by sellers. ${ }^{1}$

In contrast, in markets for commodities or securities, where there is an auctioneer or a process enforcing market clearing (as in the Cournot model), or in industries like construction, where a big buyer enforces sealed bidding (as in the Bertrand model), firms are caught in a prisoner's dilemma where they have to predict their competitors' outputs or prices, respectively. And then a firm can use non-cooperative game theory to derive rational predictions of a self-enforcing agreement conditional on specific assumptions on market conditions and firms' information on market conditions. ${ }^{2}$

Thus, in this paper we focus on markets where buyers take prices as given and prices are set by sellers, as in most consumer markets. We also focus on the short run, when firms, costs, capacities and other market conditions can be taken as given during some

\footnotetext{
1 However, extending the Boulding model to include non-price competition cannot be done without game theory, as an example in Appendix 1 shows.

2 The relation between competitive price leadership and monopolistic competition is discussed in Appendix 2.
} 
time, which I call a market period (for example a year or a quarter). More precisely, this paper deals with markets with the following characteristics:

Assumption 1 Buyers are price takers.

By assuming that buyers take prices as given we assume that buyers can observe prices at any time, but we also exclude indeterminacy due to haggling or bargaining. The exclusion of haggling reduces transaction costs and facilitates price comparisons. By excluding bargaining we exclude the possibility for buyers to bargain with producers over prices, as in many business-to-business markets or markets with 'buying groups'.

Assumption 2 Prices are set by sellers after a short period of price adjustment when firms can observe and revise their prices at any time.

In a market where buyers take prices as given trade cannot start until prices have been announced by the sellers. Preliminary list prices may be announced independently by firms, but firms are not committed to these prices as in sealed bidding (and Bertrand models). Instead firms can observe their competitors' prices and adjust their own if they want to. They can even set the same price as another firm. I interpret the end of the adjustment process as acceptance: price adjustment does not end until all firms accept competitors' prices by not reacting to them.

Prices are kept constant by firms until market conditions change. Thus, all consumers can take prices as given (constant) for some time, which greatly facilitates their planning. All firms can also take prices as given during the market period, as in the classical model of perfect competition. However, I do not exclude by assumption the possibility that production is restricted by sales at prices chosen by firms.

In fact, a firm only produces what it can sell if this is less than what it wants to sell at the price it sets. This is always true with production to orders and approximately true with production to stock. More precisely, with production to stock, as in most consumer markets (where customers usually have to visit shops to find what they want to buy), a firm has to anticipate its sales at the price it sets. In this case production will in general differ from sales and the difference will change the firm's inventories. But we can often assume that such changes are negligible, so that output equals sales even in markets where production precedes sales, at least approximately and when sales do not depend on production. ${ }^{3}$

Assumption 3 Price differentials are negligible (the law of one price).

The concept of a market price is fundamental to the concept of a market and is applicable also to markets with differentiated goods, even if it then has to be interpreted as a measure of the price level. Thus, if price differentials persist, due to heterogeneity or switching costs, I define the market price as the average of all prices (perhaps weighted with firms' market shares) or as the price of a price leader if there is oneas in this paper. Deviation from the market price can be interpreted, for instance, as

\footnotetext{
3 In practice remaining inventories sometimes give rise to a sale at the end of the market period, but this is not the same as revising the regular price set in the beginning of the market period. Markets where sales do depend on production are discussed in Farm (1988).
} 
compensation for quality above (or below) the average. But note that this paper, when applied to product differentiation, does not attempt to explain price differentials, only the price level.

\section{Assumption 4 Firms cannot form binding agreements.}

Thus we exclude the possibility for firms to jointly fix market prices or market shares and implicitly postulate the existence of a competition authority which can prevent collusion.

Without Assumption 4 any number of collusive outcomes is possible and pricing consequently indeterminate. Assumptions 3 and 4 imply that a rational firm will form preferences on market prices and prefer that market price (price level) which maximizes its individual profits, not its industry's profits. And a firm's profits at a given market price will depend on its market share as determined by consumers and capacities_-as we shall now see.

\section{Price competition and market sharing}

In a market with price leadership the problem of a price taker is simple: it sets the same price as the price leader and produces what it can sell at this price or, if its production is not restricted by what it can sell, what it wants to sell. The problem of a profitmaximizing price maker is partly the same as it is for a monopolist, i.e., estimating the industry's product demand and especially its price elasticity. In addition, however, a price leader has to estimate its market share at different market prices, including prices above the market-clearing level.

To see more in detail how market shares are determined, and also to see why firms may prefer different market prices, we begin by writing profits for firm $i$ as

$$
\pi_{i}=p q_{i}-c_{i} q_{i}-f_{i}, \quad i=1,2, \ldots, n,
$$

where $p$ is the market price, $q_{i}$ a firm's production (equal to its sales), $c_{i} q_{i}$ its variable (direct) costs and $f_{i}$ its fixed (indirect) costs.

We also assume that a firm's marginal $\operatorname{cost} c_{i}$ is constant up to a certain level of production-its capacity $k_{i}$-where it becomes so strongly increasing that its potential output of goods can be approximated by its capacity even for high prices, so that $q_{i} \leq k_{i}$ for every market price. This is probably not only a useful first approximation but also rather realistic, since a firm's supply curve for high prices is usually rather steep due to constraints on employment in current premises and with current machinery and restrictions on overtime.

Let $D$ denote the industry's demand function and suppose that $p^{k}>c_{i}$ for every $i$, where $p^{k}=D^{-1}(K)$ and $K=\sum_{i=1}^{n} k_{i}$. If the market price $p$ clears the market, $p=$ $p^{k}$, then a firm's market share is $k_{i} / K$. Suppose now that a firm's market share is proportional to its capacity even for higher prices. (This happens, for instance, if investment in outlets has been adjusted to capacities.) Then a firm's profit as a function of the market price will be

$$
\pi_{i}=\left(p-c_{i}\right)\left(k_{i} / K\right) D(p)-f_{i} \text { if } p \geq p^{k},
$$


so that a firm prefers max $\left(p_{i}^{m}, p^{k}\right)$ as market price if $p_{i}^{m}$ maximizes $\left(p-c_{i}\right) D(p)$.

It follows, firstly, that the market clears endogenously if $p_{i}^{m}<p^{k}$ for some firm. Secondly, if $p^{k}<p_{i}^{m}$ for every firm, then firm $i$ will prefer its monopoly price $p_{i}^{m}$ as market price. But this price depends on the firm's direct cost $\left(c_{i}\right)$, and if direct costs differ, price preferences differ, and it will be the low-cost firm that determines the market price.

In general, however, a firm's market share at high market prices is not necessarily the same as it is at the market-clearing price. This is because at higher prices buyers are less restricted by firms' capacities than at the market-clearing price. Of course, at the market-clearing price a buyer can always find a seller. But the seller is not necessarily the buyer's first choice. And if market shares are determined entirely by buyers' first choice - and not by firms allocating market shares through a common sales organisation - then market shares are not necessarily the same as they are at the market-clearing price.

For example, if firms are identical in every respect except capacity, the probability that a consumer chooses to buy from a particular firm will be $1 / n$ if there are $n$ firms, and it follows from the law of large numbers that each firm's market share will be $1 / n$ if $D(p) / n \leq k_{i}$ for every firm. However, if some firms' capacities are so small that $D(p) / n>k_{i}$ for some $p$, then $q_{i}=k_{i}$ for these firms even for some market prices above $p^{k}$, implying that their market shares decrease as the market price goes down. Hence a firm with a large capacity will find that its market share and sometimes also its profits will increase as the market price decreases, as elaborated in the following section.

Moreover, unless the market price clears the market, firms can increase their market shares at a given market price by offering products with characteristics that cannot easily be imitated. For example, as noted by Boulding (1941, p. 612), firms selling gasoline for the same price can have different market shares due to different locations. Thus, product differentiation implies implicit non-price competition in the sense that firms setting the same price can win customers by an attractive "design" (which doesn't necessarily increase costs). Hence the possibility of unequal markets shares is not excluded in the following section.

\section{Price leadership by a dominant firm}

We shall now see, first, how a new firm can make it profitable for a monopolist to lower its price and, second, how many competitors with small capacities can force a big firm to set a price approaching even competitive levels, as in the classical model of a dominant firm (Scherer 1980, p. 233). But we shall also see that a dominant firm will sometimes stick to monopoly pricing. And finally we shall see how the Boulding model in some cases predicts fluctuations between a high-price regime and a low-price regime as an industry develops. 


\subsection{The classical case}

Consider a firm with capacity $k^{\prime}$ which enters a monopoly market where the monopolist has capacity $k$ and direct $\operatorname{cost} c$. Suppose that the new firm takes the market price set by the ex-monopolist as given, and suppose also that its capacity is so small that it can sell everything it wants to sell at the monopoly price. This assumption models a firm which adjusts its capacity to modest expectations on sales (or which underestimates its ability to divert sales from the big firm). But it also means that the monopolist's profits (excluding fixed costs) will be reduced to

$$
\pi^{r}=(p-c)\left(D(p)-k^{\prime}\right) \text { if } p^{k} \leq p \leq p^{m}
$$

where $D$ denotes the industry's demand function,

$$
\begin{gathered}
p^{m}=\arg \max (p-c) D(p), \text { and } \\
p^{k}=D^{-1}\left(k+k^{\prime}\right) .
\end{gathered}
$$

Differentiation yields

$$
d \pi^{r} / d p=D(p)(\alpha(p)-\varphi(p)) \quad \text { if } p^{k} \leq p \leq p^{m},
$$

where $\alpha(p)$ denotes the price leader's market share at the market price $p$,

$$
\begin{gathered}
\alpha(p)=1-k^{\prime} / D(p), \text { and } \\
\varphi(p)=\mu(p) \eta(p),
\end{gathered}
$$

where $\mu(p)=(p-c) / p$ and $\eta(p)=-p D^{\prime}(p) / D(p)$. Note that $\varphi(p)$ is increasing in $p$ (assuming that $\eta(p)$ is non-decreasing in $p$ ) with $\varphi(c)=0$ and $\varphi\left(p^{m}\right)=1$, while $\alpha(p)$ is decreasing in $p$.

It follows from (6) that $d \pi^{r} / d p>0$ at $p=p^{k}$ if $\alpha\left(p^{k}\right)>\varphi\left(p^{k}\right)$ or, equivalently, $p^{o}>p^{k}$, where $p^{o}$ is defined by

$$
p^{o}=\arg \max (p-c)\left(D(p)-k^{\prime}\right)
$$

and determined implicitly by the equation

$$
\varphi\left(p^{o}\right)=\alpha\left(p^{o}\right)
$$

On the other hand, even if $p^{m}>p^{k}$ or, equivalently, $\varphi\left(p^{k}\right)<1$, it may happen that the market-clearing price $p^{k}$ maximizes profits, namely if $\alpha\left(p^{k}\right)<\varphi\left(p^{k}\right)$ or, equivalently, $p^{o}<p^{k}$. Thus, instead of a monopolist setting $\max \left(p^{m}, p^{k}\right)$ we now have a price leader setting $\max \left(p^{o}, p^{k}\right)$. Note that $\max \left(p^{o}, p^{k}\right)=p^{o}$ if $p^{k}<c$ and that in this case $p^{o} \rightarrow c$ as $k^{\prime} \rightarrow D(c)$. This completes the proof of the following result: 
Proposition 1 A price leader with capacity $k$ and direct cost $c$ will set a market price equal to $\max \left(p^{o}, p^{k}\right)$ if a single price taker can sell all it wants to sell at every market price. Here $p^{k}$ is the market-clearing price, $D\left(p^{k}\right)=k+k^{\prime}$, where $k^{\prime}$ is the capacity of the price taker, while $p^{o}$ is defined by (9) and determined by (10). Moreover,

$$
\text { if } p^{k}<c \text { then } \max \left(p^{o}, p^{k}\right)=p^{o} \text { and } p^{o} \rightarrow c \text { as } k^{\prime} \rightarrow D(c) \text {. }
$$

Thus, the dominant firm sets a price which is decreasing in the competitor's capacity. This may show how a (myopic) price leader adjusts its price over time to successive increases of a (single) competitor's capacity, since $p^{o}$ implies a local profit maximum. But even if the competitor some time ago with a small capacity could sell all it wanted to sell at $p^{m}$, this need not be the case with a large capacity. Increasing the price discontinuously from $p^{o}$ to $p^{m}$ may consequently at some point be profitable for the price leader. The crucial question is what the price leader's market share will be at $p^{m}$ when sales are restricted only by the customers' first choice, as discussed below.

Suppose, on the other hand, that the price leader has a large number of competitors with small capacities, or that we replace a single competitor with increasing capacity by an increasing number of firms with small capacities adding up to $k^{\prime}$. In this case we cannot exclude the possibility that every small firm is able to sell all it wants to sell at $p^{m}$. (For with product differentiation we cannot exclude the possibility that every customer prefers the product from one of the small firms instead of the big firm.) And even if we don't have $k^{\prime}=D\left(p^{m}\right)$, implying that the price leader sells nothing at $p^{m}$, it may happen that $D\left(p^{m}\right)-k^{\prime}$ is so small that it is not profitable for the price leader to raise its price from $p^{o}$ to $p^{m}$. The classical model of a dominant firm is an approximation of this special case.

\subsection{Monopoly pricing}

Suppose next that a new firm entering a monopoly market has invested in a relatively large capacity, so large that its market share $\beta$ at $p^{m}$ is determined not by its capacity $k^{\prime}$ but by the consumers' first choice, so that

$$
\beta D\left(p^{m}\right)<k^{\prime}
$$

Thus, at $p^{m}$ the monopolist will find its market share reduced to $1-\beta$ but it cannot be certain that its market share will increase as it lowers its price unless it reduces the market price so much that its competitor's production will be restricted by its capacity, which happens at prices below $\bar{p}$ determined by

$$
\beta D(\bar{p})=k^{\prime}
$$

Of course, profits according to (3) still applies for prices between $\bar{p}$ and $p^{k}$. But for prices between $p^{m}$ and $\bar{p}$ markets shares are determined entirely by consumers' first choice, and without additional information on consumer preferences we can only 
assume that market shares are independent of the market price, so that the price leader's profits (excluding fixed costs) will be

$$
\pi(p)=(p-c)(1-\beta) D(p) \text { if } \bar{p} \leq p \leq p^{m} .
$$

The price leader's profit is consequently decreasing as the market price is reduced from $p^{m}$ to $\bar{p}$ (assuming that $(p-c) D(p)$ is increasing up to $\left.p^{m}\right)$. It is also decreasing as the market price decreases below $\bar{p}$ if $p^{o}>\bar{p}$, since $\pi^{r}(p)$ decreases as $p$ decreases below $p^{o}$. Hence we have the following result:

Proposition 2 A price leader with a single price taker will set the monopoly price $p^{m}$ if $\beta D\left(p^{m}\right)<k^{\prime}$ and $p^{o}>\bar{p}$, where $\beta$ is the price-taker's market share at $p^{m}$ and $k^{\prime}$ its capacity, while $p^{o}$ and $\bar{p}$ are defined by (9) and (13).

To see what the condition $p^{o}>\bar{p}$ implies we first note that $p^{o}>\bar{p}$ if $D\left(p^{o}\right)<$ $D(\bar{p})$ and that $D(\bar{p})=k^{\prime} / \beta$ according to (13). Next we assume (for simplicity) that the demand function is linear, in which case $D\left(p^{o}\right)=D\left(p^{m}\right)+k^{\prime} / 2$ (as Appendix 3 shows) and $p^{o}>\bar{p}$ if $D\left(p^{m}\right)+k^{\prime} / 2<k^{\prime} / \beta$, so that

$$
p^{o}>\bar{p} \text { if } k^{\prime} / D\left(p^{m}\right)>\frac{\beta}{1-\beta / 2} .
$$

Thus, the price leader will not reduce the market price below the monopoly level if the price-taker's capacity $k^{\prime}$ is "sufficiently large". The intuition is, of course, that a larger $k^{\prime}$ will make it less profitable for the price leader to reduce the market price so much that the competitor's sale is restricted by capacity.

\subsection{Switching between pricing regimes}

But what happens if $p^{o}<\bar{p}$ ? The following result is obvious:

Proposition 3 If $p^{o}<\bar{p}$ and $\pi^{r}\left(p^{o}\right)>\pi\left(p^{m}\right)$ it is profitable for the price leader to cut its price to $p^{o}$ even when $\beta D\left(p^{m}\right)<k^{\prime}$.

But can this happen? To check this when the demand function is linear we first note that

$$
p^{o}<\bar{p} \text { if } k^{\prime} / D\left(p^{m}\right)<\frac{\beta}{1-\beta / 2} .
$$

Moreover, it is easy to prove (see Appendix 3) that

$$
\pi^{r}\left(p^{o}\right)=\left(p^{m}-c\right) D\left(p^{m}\right)\left(1-k^{\prime} / 2 D\left(p^{m}\right)\right)^{2} .
$$

And since

$$
\pi\left(p^{m}\right)=\left(p^{m}-c\right)(1-\beta) D\left(p^{m}\right)
$$

it follows that

$$
\pi^{r}\left(p^{o}\right)>\pi\left(p^{m}\right) \text { if }\left(1-k^{\prime} / 2 D\left(p^{m}\right)\right)^{2}>1-\beta \text { or, equivalently, }
$$




$$
\pi^{r}\left(p^{o}\right)>\pi\left(p^{m}\right) \text { if } k^{\prime} / D\left(p^{m}\right)<2\left(1-(1-\beta)^{1 / 2}\right) .
$$

We conclude that $p^{o}$ is profit-maximizing even when $\beta<k^{\prime} / D\left(p^{m}\right)$ if, with $k^{\prime} / D\left(p^{m}\right)=x$,

$$
x>\beta \text { and } x<\frac{\beta}{1-\beta / 2}=f_{1}(\beta) \text { and } x<2\left(1-(1-\beta)^{1 / 2}\right)=f_{2}(\beta) .
$$

Note that $f_{1}(0)=f_{2}(0)=0$ and $f_{1}(1)=f_{2}(1)=2$, so it is easy to see that (21) is satisfied for some $x$ if $\beta$ is sufficiently large.

These arguments suggest that there can be two different "pricing regimes" in a market, and also that the market price can change either continuously or discontinuously as market conditions change, and either upward or downward, depending on the number of firms in the industry and their capacities, but also depending on the way the market is shared between firms when sales are determined by consumers' first choice. And the "tipping point", when the price leader is indifferent between setting a high price and a low price, is determined by $\pi\left(p^{m}\right)=\pi^{r}\left(p^{o}\right)$. If this equality holds at least approximately, then the market price set by the price leader will be very sensitive to the price leader's estimates of its competitors' capacities as well as their market shares at the monopoly price.

\section{Conclusions}

Price leadership postulates the possibility for firms to set the same price as another firm, which is a reasonable assumption in markets where sellers are free to observe and revise their prices at any time. And while setting the same price as another firm-being a price taker-suggests collusion in markets with sealed bidding, it is perfectly legal in consumer markets.

Competitive price leadership means that pricing is not collusive (maximizing the industry's profits). A low-cost firm prefers a lower market price than high-cost firms and will also enforce it. And if a firm by price cutting can increase its market share so much that its profits increase even if its competitors follow suit, then it will also cut its price. Price leadership by a dominant firm is a classical example, and we have seen in detail when and why the presence of competitors will force a big firm to abandon monopoly pricing. Thus, price leadership does not exclude price competition, only price competition which reduces profits for every firm. Note also that market clearing is established endogenously by competitive price leadership if all firms in an industry are producing at full capacity and a higher market price would reduce profits for at least one firm.

\section{Appendix 1: Effects of marketing in consumer markets}

Unless the market price clears the market, firms try to increase their market shares by attracting customers in ways which cannot easily be imitated by their competitors. Even if market shares have been mainly determined before the market period, some 
marketing may also occur during the market period, when the market price has been set, particularly advertising and distribution, and such competition cannot be ignored, since it will affect the profits of each firm. But then firms are caught in a prisoner's dilemma where the outcome depends on actions they cannot observe until (possibly) at the end of the market period. When estimating profits as a function of the market price, firms consequently have to predict the effects of marketing on profits, and then they can be assisted by game theory.

In Sect. 4 we have seen that a local maximum for a price leader can differ from the global maximum and that the global maximum implies a higher market price than the local maximum. In this appendix we shall see that with costly marketing a global maximum can also imply a lower market price.

Following Shubik with Levitan (1980, p. 192), we assume that a firm's market share is

$$
\rho_{i}=(1-\gamma) \beta_{i}+\gamma a_{i} / \sum a_{j}, \quad 0 \leq \gamma \leq 1,
$$

where $\beta_{i}$ denotes its market share in the absence of marketing, $a_{i}$ denotes the firm's expenditures on marketing and $\gamma$ measures the effect of this marketing, assumed to be the same for every firm.

Shubik with Levitan (1980) interprets $a_{i}$ as expenditures on advertising and $\gamma$ as the proportion of customers who are influenced by advertising, but other interpretations are possible, like distribution of goods to shops, provided they only include measures which are made and have effects during the market period. Assuming that there are $n$ firms, the predetermined market shares $\beta_{i}$ may be equal to $1 / n$ or not.

Now, when deriving profits as a function of the market price, a firm has to anticipate the effects of marketing on profits. And with marketing technology according to (22) a firm's profit (excluding fixed costs) in an industry with demand function $D$ and market price $p$ is

$$
\pi_{i}=(p-c) D(p)\left[(1-\gamma) \beta_{i}+\gamma a_{i} / \sum a_{j}\right]-a_{i},
$$

assuming in addition that all firms have the same direct cost $(c)$. It follows that

$$
\partial \pi_{i} / \partial a_{i}=(p-c) D(p) \gamma \frac{1-a_{i} / A}{A}-1,
$$

where $A=\sum a_{j}$, so that in equilibrium at $p>c$, where $\partial \pi_{i} / \partial a_{i}=0$,

$$
\begin{gathered}
a_{i} / A=\text { constant }=1 / n, \\
A=(p-c) D(p) \gamma(1-1 / n), \\
\pi_{i}=(p-c) D(p)\left[(1-\gamma) \beta_{i}+\gamma / n^{2}\right] .
\end{gathered}
$$

Marketing will consequently affect profits but not preferred prices in equilibrium, implying that every firm prefers $p^{m}=\arg \max (p-c) D(p)$ as the market price.

But how can this equilibrium solution guide firms in practice? First, if all firms have the same direct costs (and know this) they see from (27) that they all prefer the same market price, independent of $\beta_{i}$ and $\gamma$. Moreover, a firm's profit is a linear function of 
the effect of marketing as measured by $\gamma$, with $\pi_{i}=\beta_{i} \pi^{m}$ for $\gamma=0$ and $\pi_{i}=\pi^{m} / n^{2}$ for $\gamma=1$, where $\pi^{m}=\left(p^{m}-c\right) D\left(p^{m}\right)$. Thus, all firms, but in particular firms with large initial market shares $\left(\beta_{i}>1 / n\right)$, loose a lot if marketing has a strong effect, and the loss depends strongly on the number of firms.

It may consequently be very profitable for all firms to reduce marketing by a binding agreement to abstain from it. If in addition marketing does not create additional value for customers, like advertising for a homogenous good, such an agreement would not hurt the customers. On the other hand, a competition authority should object to such an agreement if marketing benefits customers, for example by making products more easily available in shops. In any case, if marketing has strong effects on market shares, it will always be very tempting for a firm to break an agreement.

Moreover, introducing capacity constraints, and assuming (for simplicity) that all firms have the same capacity $(k)$ and the same market share in the absence of marketing $\left(\beta_{i}=1 / n\right)$, a firm's profits as a function of the market price $p$ (in equilibrium) will be

$$
\begin{gathered}
\pi_{i}(p)=(p-c) D(p) / m \text { if } p>p^{k}, \\
\text { where } 1 / m=(1-\gamma) / n+\gamma / n^{2} \text { and } D\left(p^{k}\right)=K=n k, \\
\text { while } \pi_{i}(p)=(p-c) k \text { if } p \leq p^{k}
\end{gathered}
$$

It follows that every firm prefers $p^{k}$ to $p^{m}$ if

$$
\left(D^{-1}(K)-c\right) K / n>(p-c) D(p) / m
$$

and hence that every firm prefers $p^{k}$ to $p^{m}$ if $K<K_{d}$, where $K_{d}$ is determined by

$$
\left(D^{-1}\left(K_{d}\right)-c\right) K_{d}=((1-\gamma)+\gamma / n)\left(p^{m}-c\right) D\left(p^{m}\right) .
$$

In this case a price leader will set a market-clearing price $p^{k}$ not only if $K \leq D\left(p^{m}\right)$, as in a price leader model with exogenous market shares. Instead we have market clearing and a market price below $p^{m}$ if $K \leq K_{d}$, with $K_{d}$ even approaching $D(c)$ as $n \rightarrow \infty$ if $\gamma=1$. The threat of costly competition for market shares in excess-capacity situations may consequently enforce a market-clearing price below the monopoly price even when firms are identical.

\section{Appendix 2: On monopolistic competition}

This appendix relates monopolistic competition (MC) to competitive price leadership (CPL). Both approaches apply to markets where firms offer close but imperfect substitutes, as in most consumer markets. However, while CPL focuses on the determination of the market price (price level) and says nothing about price differentials, MC offers a complete solution of all individual prices in the following way. 
Consider an industry with $n$ firms producing differentiated goods and suppose that the demand for output from firm $j$ depends (continuously) on the prices of all firms,

$$
q_{j}=D_{j}(p)
$$

where $p$ is the vector of all prices. The profits of firm $j$ are given by

$$
\pi_{j}(p)=p_{j} D_{j}(p)-C_{j}\left(D_{j}(p)\right)
$$

where $p_{j}$ is the price set by firm $j$ and $C_{j}\left(D_{j}(p)\right)$ is the cost for firm $j$ of producing the demand for its output. An equilibrium with monopolistic competition is defined as a price vector $p^{*}=\left(p_{1}^{*}, \ldots, p_{n}^{*}\right)$ such that for every $p_{j}^{*}$,

$$
p_{j}^{*}=\arg \max \pi\left(p_{j}, p_{-j}^{*}\right)
$$

where $p_{-j}^{*}$ is the vector of all $p_{i}^{*}$ but $p_{j}^{*}$.

This concept of endogenous pricing eliminates some of the existence problems noted by Edgeworth in Bertrand models with perfect substitutes and capacity constraints but, as emphasized by Benassy (1991, p. 2007), not all of them. Moreover, as also emphasized by Benassy (1991, p. 2031) objective demand curves are "very complex objects requiring that each price setter has as much information on the economy as the model maker himself, quite a strong assumption".

Thus, "the theory of monopolistic competition ... poses important and difficult conceptual problems" (Benassy 1991, p. 1999). In fact, an equilibrium approach to pricing is incomplete as a theory of price making unless it also tells us how equilibrium prices are reached in practice. The theory of perfect competition illustrates such an equilibrium approach since equilibrium prices are first determined by a set of equations and then supplemented by a theory of adjustment which, however, presupposes extreme and irrational price competition.

In contrast to perfect competition, monopolistic competition is a Nash equilibrium and often also a Nash equilibrium in pure strategies. And the concomitant theory of adjustment to equilibrium is not a story of extreme price competition but related to an (implicit) assumption of perfect information on objective demand functions and competitors' cost functions, an assumption which permits rational predictions of a self-enforcing agreement on prices which all firms set independently and stick to as long as market conditions are unchanged.

Thus, while perfect competition interpreted as a theory of price making presupposes extreme price competition, monopolistic competition interpreted as a theory of price making presupposes extreme knowledge. A possible interpretation of competitive price leadership is that it is an approximation of monopolistic competition with demands for information sufficient to determine the price level but not price differentials.

Competitive price leadership (CPL) is certainly an approximation, even if it suggests that price differentials are small, but it also offers an alternative approach to pricing. Instead of first defining an equilibrium in prices and then add a theory of adjustment, 
CPL is an example of a behavioural approach to pricing, characterized by focusing directly on how prices are set, given the rules of the market game and the information available to price setters in practice.

Note that Boulding offers a solution to the existence problems in BertrandEdgeworth models which is simpler than the solution suggested by Chamberlin-but it is only applicable to markets where buyers take prices as given, as in consumer markets. Note also that monopolistic competition (MC) has a competitive bias. This follows from the basic equilibrium condition (35), which makes price cutting tempting almost exactly as in perfect competition. More precisely, equilibrium is not yet attained if a firm finds it profitable to cut its price when its competitors' prices are taken as given. And this implies that substitutability between goods adds to the market's "competitiveness" as measured by the contribution margin $\left(p_{j}^{*}-C^{\prime}\left(q_{j}^{*}\right)\right) / p_{j}^{*}$ (also called Lerner's degree of monopoly), as shown by (Benassy 1991, p. 2011). In contrast, in a Boulding model a high degree of substitutability between two goods suggests that the price differential will be small, but it says nothing about the price level. And while "market size" (number of firms) also matters for competitiveness in some MC models with capacity constraints, as (Benassy 1991, p. 2014) shows, the effect of "market size" is easy to study in all CPL models, as Sect. 4 in this paper illustrates.

\section{Appendix 3: Some proofs}

When discussing Propositions 2 and 3 in Sect. 4 the following results on a linear demand function $D$ are used. First, define $p^{e}$ and $p^{f}$ by

$$
D\left(p^{e}\right)=0 \text { and } D\left(p^{f}\right)=k .
$$

Moreover, define $p^{m}$ and $p^{o}$ by

$$
p^{m}=\arg \max (p-c) D(p) \text { and } p^{o}=\arg \max (p-c)(D(p)-k),
$$

and note that

$$
p^{m}=c+\left(p^{e}-c\right) / 2, \quad D(c)=2 D\left(p^{m}\right), \quad \text { and } \quad p^{o}=c+\left(p^{f}-c\right) / 2 \text {. }
$$

The linear demand function can now be written as

$$
D(p)=D(c)\left(1-\frac{p-c}{2\left(p^{m}-c\right)}\right) .
$$

Substituting $p^{f}$ in (39) we obtain

$$
k=D\left(p^{f}\right)=D(c)\left(1-\frac{p^{f}-c}{2\left(p^{m}-c\right)}\right)=D(c)\left(1-\frac{2\left(p^{o}-c\right)}{2\left(p^{m}-c\right)}\right),
$$


and hence also

$$
p^{o}-c=\left(p^{m}-c\right)(1-k / D(c)) .
$$

Substituting $p^{o}$ in (39) and using (41) and (38) we obtain

$$
D\left(p^{o}\right)=D(c)\left(1-\frac{p^{o}-c}{2\left(p^{m}-c\right)}\right)=D(c)\left(1-\frac{1}{2}\left(1-\frac{k}{D(c)}\right)\right)=D\left(p^{m}\right)+k / 2 .
$$

It follows from (41) and (42) that

$$
\left(p^{o}-c\right)\left(D\left(p^{o}\right)-k\right)=\left(p^{m}-c\right)(1-k / D(c))\left(D\left(p^{m}\right)-k / 2\right),
$$

and combining this with $D(c)=2 D\left(p^{m}\right)$ we find that

$$
\left(p^{o}-c\right)\left(D\left(p^{o}\right)-k\right)=\left(p^{m}-c\right) D\left(p^{m}\right)(1-k / D(c))^{2} .
$$

Open Access This article is distributed under the terms of the Creative Commons Attribution 4.0 International License (http://creativecommons.org/licenses/by/4.0/), which permits unrestricted use, distribution, and reproduction in any medium, provided you give appropriate credit to the original author(s) and the source, provide a link to the Creative Commons license, and indicate if changes were made.

\section{References}

Benassy JP (1991) Monopolistic competition. In: Hildenbrand W, Sonnenschein H (eds) Handbook of Mathematical Economics, vol IV, 1997-2045. North-Holland

Boulding KE (1941) Economic analysis. Harper and Brothers, New York

Deneckere RJ, Kovenock D (1992) Price leadership. Rev Econ Stud 59:143-162

Farm A (1988) Cooperative oligopolistic pricing. Eur J Polit Econ 4:13-28

Hviid M (1990) Sequential capacity choice and price choices in a duopoly model with demand uncertainty. J Econ 51:121-144

Ishibashi I (2008) Collusive price leadership with capacity constraints. Int J Ind Organ 26:704-715

Lanzillotti RF (1957) Competitive price leadership—a critique of price leadership models. Rev Econ Stat 39:55-64

Luce RD, Raiffa H (1957) Duncan and Howard Raiffa. Games and Decisions. Wiley, New York

Markham JW (1951) The nature and significance of price leadership. Am Econ Rev 41:891-905

Pastine I, Pastine T (2004) Cost of delay and endogenous price leadership. Int J Ind Organ 22:135-145

Rotemberg JJ, Saloner G (1990) Collusive price leadership. J Ind Econ 39:93-111

Scherer FM (1980) Industrial market structure and economic performance, 2nd edn. Houghton Mifflin, Boston

Seaton JS, Waterson M (2013) Identifying and characterising price leadership in British supermarkets. Int J Ind Organ 31:392-403

Shubik M, Levitan R (1980) Market structure and behavior. Harvard University Press, Cambridge Stigler GJ (1947) The Kinky Oligopoly Demand Curve and Rigid Prices. J Polit Econ 55:432-449 